Regina Celia Fiorati ${ }^{1}$ Toyoko Saeki ${ }^{2}$
${ }^{1}$ Curso de Terapia

Ocupacional. Faculdade de

Medicina de Ribeirão Preto.

Universidade de São Paulo.

Av. Bandeirantes 3900 ,

Monte Alegre. 14.049-900

Ribeirão Preto SP.

reginacf@fmrp.usp.br

${ }^{2}$ Escola de Enfermagem de

Ribeirão Preto,

Universidade de São Paulo.

\section{The prevalence of medical/clinical technology over psychosocial care actions in outpatient mental health services}

\author{
Predominância da tecnologia médico-clínica sobre ações de \\ atenção psicossocial em serviços extra-hospitalares de saúde mental
}

\begin{abstract}
The scope of this study was to evaluate how aspects of mental health policy in Brazil have been conceived and implemented in outpatient services, such as the Regional Outpatient Mental Health Clinic and the Psychosocial Care Center II, both in Ribeirão Preto, São Paulo. Semi-direct interviews and focus groups were conducted with 22 health professionals. The theoretical method and data analysis were supported by the dialectical hermeneutic framework of Jürgen Habermas. The following aspects were detected: considerable technological advancement in health actions and centrality of clinical-medical technology in relation to other nonmedical therapeutic actions; the prioritization of treatment options emphasizing pathology and drug therapy, and a process of mounting precariousness in labor relations. With respect to psychosocial rehabilitation, analysis revealed that instrumental and technically-oriented treatment is imposed upon the practical and dialogical rationale proposed by Brazilian Psychiatric Reform. As an alternative, participatory evaluative research is required in order to unify clinical and psychosocial rehabilitation actions in therapeutic projects, while establishing mechanisms to promote the improvement of care based on the psychosocial care model.
\end{abstract}

Key words Mental health, Outpatient mental health services, Psychosocial care, Psychosocial rehabilitation
Resumo O objetivo deste trabalho foi avaliar de que forma aspectos da política de saúde mental brasileira têm sido construídos e efetivados em serviços extra-hospitalares, como o Ambulatório Regional de Saúde Mental e o Centro de Atenção Psicossocial II, ambos de Ribeirão Preto, São Paulo. Entrevistas semidiretivas e grupos focais foram realizados com 22 profissionais da saúde. O método teórico e a análise dos dados apoiaram-se no referencial hermenêutico dialético de Jürgen $\mathrm{Ha}$ bermas. Observou-se alta tecnificação das ações de saúde, centralidade da tecnologia médico-clínica em relação a outras ações terapêuticas não médicas, priorização de formas de tratamento com ênfase na patologia e na terapêutica medicamentosa e um processo de precarização das relações de trabalho. Com relação à reabilitação psicossocial, foi observado que o tratamento instrumental e tecnificado se impõe à racionalidade prática e dialógica preconizada pela Reforma Psiquiátrica Brasileira. Como alternativa, é necessária a realização de pesquisa avaliativa participativa com objetivo de unir ações clínicas e de reabilitação psicossocial em projetos terapêuticos e de criar mecanismos que favoreçam a melhoria da assistência prestada com base no modo de atenção psicossocial.

Palavras-chave Saúde mental, Serviços extrahospitalares de saúde mental, Atenção psicossocial, Reabilitação psicossocial 


\section{Introduction}

Extra-hospital mental health services emerged from the need to replace psychiatric facilities with a community-based health care model. These services are organized and based on the Psychiatric Reform that began in Europe and the United States at the end of the 1950s and mainly intensified from 1960 on. In Brazil, such a movement began in the 1970s and its peak occurred in the 1980s and 1990s. Extra-hospital devices were created within the Unified Health System (SUS) such as Psychosocial Care Nucleus (NAPS), Psychosocial Care Centers, Community Centers (CAPS), day-hospitals, therapeutic houses, outpatient clinics, social support programs, and services for the defense and promotion of human rights of patients and families ${ }^{1}$.

Psychosocial Care Centers (CAPS) were created to work with a multi-professional staff and a number of activities broad enough to encompass therapeutic and creative workshops and physical and playful activities, in addition to the patients' medication scheme. Additionally, the family should be fully included in the context of the patient's treatment ${ }^{2}$.

Extra-hospital mental health services currently integrate an important re-structured psychiatric care network. Such services compose the central guidelines of Brazilian mental health policies established by the Ministry of Health and guided by the Brazilian Psychiatric Reform ${ }^{3}$.

According to Amarante ${ }^{4}$, these guidelines are summarized as initiatives to progressively and gradually reduce the number of beds in psychiatric facilities, to ensure care is provided to patients discharged from hospitals, and the creation and maintenance of the extra-hospital network. Additionally, according to the Brazilian Mental Health policies, some notions should have greater importance such as: the conception of interdisciplinary work; integral health actions; the idea of thoughtfully and considerately receiving patients into the service, and the implementation of therapeutic listening, individualized therapeutic plans, psychosocial rehabilitation and social inclusion; and interventions and partnerships developed with an emphasis on actions focused on the community ${ }^{3}$.

Carrying out the study in extra-hospital mental health services was important to investigating how these services, the respective therapeutic projects and therapeutic actions available to this population, are currently organized. It also permitted evaluating whether the current organiza- tion fully meets the objectives of Brazilian Psychiatric Reform, since the process of psychosocial rehabilitation is not a technique but a strategy, which is used in the interface among the individual, his/her interpersonal network, and social context $^{5}$.

Therefore, this study sought to identify how mental health treatments have considered the clinical dimension and psychosocial actions that ground the basis of the central guidelines recommended by the Psychiatric Reform. It also verified, based on the conceptions of the professionals involved in these services, whether the extrahospital mental health services have in fact replaced the hospital-centered model with a psychosocial care network.

\section{Methodological trajectory: a participatory approach}

This study was conducted in two extra-hospital mental health services in Ribeirão Preto, SP, Brazil: the Regional Mental Health Outpatient Clinic of Ribeirão Preto and the Psychosocial Care Center II (CAPS II), from 2007 to 2009. Both are mental health referral services in the city and region. The regional outpatient clinic is the largest service for mental health care in the city, while CAPS II is the only mental health service of its kind and has a central position in the services network of this specialty.

While the CAPS II provides services to patients with severe and persistent mental disorders $^{2}$, the Regional Mental Health Clinic must provide support along with an effective CAPS network, serving less severe patients and seeking articulation with primary care teams in each territory. However, for regions without CAPs, Regional Mental Health Clinic must give support for severe mental illness, associating with primary care to monitor minor disorders ${ }^{6}$. The Regional Mental Health Outpatient Clinic evaluated in this study plays a role in this last scenario.

While the regional outpatient clinic's coverage includes a population of 330,000 inhabitants originating from the city's North, South and East and from another two cities in the region; a total of 8,000 appointments are held per year; CAPS II covers a population of 107,000 inhabitants from the Central District of Ribeirão Preto. It did not report how many appointments are performed per year.

The study's participants were professionals directly linked to patient care delivery, responsible 
for the development and implementation of work proposals and the services' therapeutic projects. The participants were nursing auxiliaries, nurses, psychologists, psychiatrists, social workers, occupational therapists, music therapists, and managers (even though the latter are in psychiatrics, they were computed as a separate group).

The project was submitted to and approved by the City Health Department in Ribeirão Preto and the Ethics Research Committee at the University of São Paulo at Ribeirão Preto. All the participants signed free and informed consent forms.

This is a qualitative research because the study's constituent elements were ideological in nature, of symbolic historical constructions, referring to concepts and meanings and, therefore, required interpretative analysis. Data were collected through semi-directed interviews and focal groups.

The semi-directed interviews contained an axis on which the interviewees were invited to discuss their work in the service, objectives, relationships with other professionals, how the therapeutic project was developed, their conception concerning psychosocial rehabilitation and whether the service had implemented psychosocial rehabilitation actions. Questions are shown in Chart 1.

The questions were read together with the participants who also had a printed copy with them. The interviews, which lasted from one hour to one hour and 30 minutes, were recorded in cassette tapes. This material was thoroughly evaluated to establish some symbolic formations and discursive messages outlining some thematic clusters. We crossed these previous topics with our specific objectives that consisted in investigating

Chart 1. Complete questions asked to the interviewees.

1- Would you please describe the work you perform in the service as well as its objectives, relating them to the other staff workers and the service's therapeutic project?

2- How is the therapeutic project developed in the service?

3- What is your conception of psychosocial rehabilitation? Would you please describe the psychosocial actions implemented in the service? the form of organization of the selected extrahospital mental health services and the constitution of the therapeutic project.

The methodology was implemented taking into account the process of knowledge production, constructed together with the health staff. For that, Jürgen Habermas' hermeneutic-dialectical framework was used. It recommends the construction of social action projects based on dialogical interaction among individuals inter-subjectively organized in a decratic manner through symmetrical imbricated discursive positions ${ }^{7}$.

A total of 19 interviews were held with the following professionals: four nursing auxiliaries, two nurses, two psychologists, two occupational therapists, three social workers, one music therapist, three psychiatrists and two managers.

After analyzing the reports' thematic content, data were grouped into analytical categories. The ones that stood out were: technique-based work centered on the expertise or specialists; medical/ clinical technology predominated over other therapeutic actions; uncertainty surrounded the development and management process of therapeutic projects; and there was a lack of psychosocial rehabilitation actions.

These categories were presented to the focal groups and a central axis was delineated for the discussion that questioned why the treatment available in the services was mainly based on medical/psychiatric actions at the expense of psychosocial rehabilitation. The focal groups discussion were also recorded in cassette tapes. In the thematic set "work organization" the discussion was focused on the technique-based health work, work centered on medical-clinical technology and precarious conditions of the services. In the theme "service organization" were discussed questions about the therapeutic projects, organization of teams and therapeutic actions. Finally, in thematic block "psychosocial rehabilitation" were discussed ideas about the actions of psychosocial rehabilitation on the projects elaborated or provided by the professionals. Most of the 19 professionals participating in the focal groups belonged to the interviewed group, with the exception of two nursing auxiliaries and one music therapist who were not present at the service on the day the focal group was held, and one nurse, one psychologist and one psychiatrist who were included at this point.

Data analysis was based on the hermeneutic dialectic philosophy of Jürgen Habermas, supported by the interpretation and understanding of discursive constructions and conceptions of 
the study's authors and subjects, and rather than on an analysis supported by the description of facts and an explanation of phenomena ${ }^{7,8}$.

\section{Results and discussion: a reconstructive interpretative analysis}

The data analysis of semi-directed interviews revealed that the organization of the studied services put an emphasis on technique-based work; professional actions were centered on each core competence to the detriment of an interdisciplinary perspective. A predominance of medical/clinical technology over other therapeutic actions was observed, which was based on: overvaluation of the medication scheme and undervaluation of psychosocial rehabilitation actions; a lack of organization among the teams collaborating on collective and interdisciplinary therapeutic projects; and poor work contracts generated within the context of municipal mental health policies. Additionally, the conceptions concerning psychosocial rehabilitation highlighted the predominant idea of a process of adaptation to standardized social behavior and that it is a function external to the services. Each of the points that resulted from the study was evaluated.

The technique-based work observed in the services stood out in the perception of the professionals focused on the core competence of their professions. Such a fact was represented by a set of types of knowledge and techniques that demarcate a given professional field. The core competence essentially contains a set of techniques learned as procedures that must be present in an intervention when in the face of certain events, previously studied and classified according to preestablished criteria.

We note that the professionals restrict themselves to applying techniques that reflect their professional specificity, which impedes the construction of a therapeutic project that is supported on broad performance in an interdisciplinary field. As a consequence, health actions are not integral and a lack of knowledge is observed. Such a lack of knowledge refers to situations that empirical reality presents at certain times, such as the specific needs of the services' users concerning the organization of their daily lives. Techniques restricted to their core competence are insufficient to provide an effective response to such needs $s^{9}$. Therefore, the challenges presented to the different groups of professionals working in community mental health services are to expand the limited knowledge of professionals concerning the concepts, values, language and activities of other fields and to encourage production that minimizes inter-profession barriers arising from the fact that the individuals' initial education took place separately ${ }^{10}$.

Professional education in the health field that is focused on the biomedical and individualized model, and which inherited examples of production and the establishment of positive knowledge related to the health-disease continuum, produces precise and objective techniques to approach the individual in his/her state of illness ${ }^{11}$. However, the phenomenon of imposing an instrumental rationale and technique over another based on interdisciplinary and dialogical elements established among the participants of an action-based project is perceived as a cultural phenomenon in contemporary society. According to Habermas ${ }^{7}$, contemporary society is marked by the imposition of an instrumental rationale over a communicative rationale. The instrumental rationale, technalized in all aspects, impedes linguistic-mediated agreements from being established in the production of social projects, removing the possibility of reaching an ethical consensus, grounded in dialog and democratic relationships among individuals.

Culture, supported on a process of de-politicization, is legitimated by a technocratic consciousness and is, at the same time, a self-objectification of individuals in categories that fuse action directed to ends with instrumental and adaptive behaviors. The science-reified models invade the sociocultural world and acquire an objective power over self-comprehension ${ }^{12}$.

Another fact observed in the studied services and that is also shown as a consequence of the previous discussion, is the organization of work centered on medical-clinical technology; the reproduction of medical technology as a technicalideological matrix is predominant. The treatment available to users emphasizes medical/psychiatric consultations, diagnosis, the psychopathological treatment and medication scheme. Hence, the work of the physician serves as a central organizer in relation to the other non-physician professionals so that medical treatment is considered absolutely necessary and indispensable. The other therapeutic activities, though, are seen as possibilities conditioned on material and human resources, but not necessarily present in the services.

In the studied services the instrumental rationale is superposed over the practical rationale. The hegemonic rationale observed in western society 
and which guides medical practice is instrumental. It bases its technology in the scientific system of positive knowledge, under all aspects of the biological, universal and generalizable sciences, and constructs certain techniques and instruments whose purpose is the success of technical healing. In contrast, psychosocial rehabilitation occurs according to a practical rationale; that is, it occurs in the context of the users' psychosocial health needs, which are related to cultural, economic, and political aspects of human relations.

The services' studied professionals revealed there is no therapeutic project with a primary philosophy guiding the actions and central objectives of care in these services. We perceive that the teams have resigned themselves from the function of developing and managing therapeutic projects and accepted instructions that come read from management agencies, whether these are municipal agencies or agencies at other government levels. The professionals may even guide their actions based on technical arrangements and technologies inherent to their own specialties.

A therapeutic project refers to any plan establishing the modus operandi of a given team of professionals. Such a plan is based on the needs of patients, which intersected with certain manners of understanding care, generates actions in the form of work. That is, a therapeutic project is a set of actions configured as the result of an interface between the professionals' technological offerings (care, knowledge and instruments) and the health needs of users, reflecting a particular work philosophy ${ }^{13}$. This would be to deconstruct existing mental health treatment modalities in order to reconstruct approaches focused on the needs of patients, which characterizes psychosocial rehabilitation ${ }^{14}$.

The therapeutic project can be evaluated as a type of founded consensus, which was described by Habermas ${ }^{8}$, to designate the process of mutual understanding among individuals. Such a process would be linguistically mediated with the purpose of coordinating social actions within a process of reasoning that permits the participants to take, as the last consequence, the principle of radical doubt. They would be free of any forms of coercion or violence, characterized by freedom to criticize and debate, maybe even leading to review or overcome systems based on certain theoretical or institutional frameworks. Additionally, all those participating in the discussion should have symmetrical possibilities in relation to choice, development, the utterance of discourses and assumption of roles in a truly dialogical situation. Ac- cording to the author, an emancipatory interest of humankind is methodologically assumed if these conditions are complied with, that is, there is an ideal communicative situation generating a truly founded consensus, in which all the participants are protagonists, interested, free and equal.

Hence, if we consider the therapeutic project as a type of founded consensus, we perceive the need for this dialogical constitution as a basic field to guide the process of project construction according to the theoretical-practical framework of the principle of integrality and broadened actions in the mental health services. To establish such a dialogical situation, however, individuals are required to manage, arrange and negotiate it. Campos ${ }^{15}$ asserts that it is necessary for the constitution of humans to be democratically organized, along with the production and strengthening of subjectivities.

There is, however, another fact to be considered in order to implement this project, which is the poor work relationships that currently exist. Deteriorating functioning conditions were observed in the studied services. The physical structure was not appropriate nor was the outpatient clinic. There is a longstanding and continuous lack of material, thus human resources and professionals are frequently overwhelmed, assuming tasks not directly linked to their functions and performing activities in a mechanical manner, not observing the patients' real health and social needs. Moreover, mental health policies have not established any practices to resolve this problem. Rather, we note that this situation has gradually arisen in recent years as a consequence of the orientation of the city's mental health policies, which seem to be aligned with positions that favor the increase of hospital beds instead of strengthening teams and organizing the work in extra-hospital mental health services.

Considering the answers given by professionals of Regional Mental Health Outpatient Clinic and CAPS II services, there are notable differences. While the staff of the Clinic is organized only in a multidisciplinary (based on the juxtaposition of roles and responsibilities for work organization fragmented by different specialties, which do not fit together in an organic form of a project coordinated by the cooperation of knowledge in order to extend each other), the CAPS team merges a multidisciplinary way with traces of interdisciplinarity.

An interesting fact is that a small part of the professionals working in the studied services and who participated in psychiatric reform conceived 
psychosocial rehabilitation as a vital device and paid attention to its devaluation in the face of the therapeutic actions that have been developed. However, most of the professionals, who joined the services more recently, considered psychosocial rehabilitation to be a method to approximate those with psychological suffering to standardized behavior and appropriate social roles, or in other cases, as actions that do not belong among the functions of mental health services and should be referred to other services, not specifically services caring for mental disorders.

An immediate consequence of this is that psychosocial rehabilitation actions were not implemented in the studied services because these require orientation and investment other than what has thus far been valued and made effective in these services. Psychosocial rehabilitation is an approach that arises from new reorganizational proposals for psychiatric care following the movement of the psychiatric reform that took place both worldwide and in Brazil. This movement is characterized as giving direction to health actions in extra-hospital mental health services aiming to bring together existential experiences resulting from mental illness of physical and sociocultural spaces, and civil legitimacy in society.

\section{Psychosocial care model: treatment and social inclusion}

The implementation of a therapeutic project needs to be based on a psychosocial care model that includes treatment actions of a clinical nature and those of psychosocial rehabilitation. Additionally, an evaluation needs to be performed in these services, coordinated by scholars, scientific agencies promoting research, and the Ministry of Health, with the participation of actors such as users, family members, professionals and managers.

Such an evaluation can support the solution of problems related to the organization of activities of each professional with an emphasis on changing conceptual and practical approaches, improving care provided to users and decisionmaking, and also transparency in the use of public funds ${ }^{16,17}$. Additionally, evaluations serve to develop programs and projects and support public policies. These can also be used to monitor processes, results and the impact of certain actions ${ }^{18}$.

\section{Final Considerations}

This study revealed how certain issues have been placed at the foundation of the process of constructing a new paradigm related to the concept of mental health and providing such care, as well as to the psychosocial care model.

Care in this field still reflects a medical/clinical and medication-based therapy, with a strictly biological and healing nature, devaluing psychosocial rehabilitation actions, whose main purpose is to enable an existential re-signification of mental illness, the creation of new forms of life, social inclusion and health promotion.

Hence, it is apparent that the implementation of the Brazilian Psychiatric Reform faces barriers, especially in relation to the development and management of interdisciplinary therapeutic projects seeking the integrality of health actions.

According to the interviewed professionals, the main obstacles originate from guidance provided by public policies in the mental health field and administrative policies at the municipal level. Such policies deviate from recommendations in the National Mental Health Policy, which reflects the objectives of Brazilian Psychiatric Reform and emphasizes a reformulated psychiatric care project based on the psychosocial care model.

So, it is important to interleave periods in which the development of new services and programs should be discussed to promote interdisciplinarity among Mental Health Services, always respecting the regional particularities and needs. Such situation emphasizes the importance of an assessment from the perspective of health professionals, the policies in Mental Health.

From this perspective, we see the need to develop an evaluative study of extra-hospital mental health services in Ribeirão Preto, SP, Brazil to find alternatives to solve the existing organizational and care deadlocks ${ }^{19}$. Additionally, it is extremely important to consider the views of the various actors imbricated in these services, such as users, family members, professionals and managers, in order to propose transformations in care delivery seeking the effective implementation of the psychosocial care model. 


\section{Collaborations}

RC Fiorati worked in the design, methodology and final draft. T Saeki worked in the methodology and revision

\section{References}

1. Amarante P. Loucos pela vida: a trajetória da Reforma Psiquiátrica no Brasil. Rio de Janeiro: SDE, ENSP; 1995.

2. Brasil. Ministério da Saúde (MS). Portaria n. ${ }^{\circ} 336 /$ GM de 19 de fevereiro de 2002. Estabelece CAPS I, CAPS II, CAPS III, CAPS i II e CAPS ad II. Diário Oficial da União 2002; 20 fev.

3. Brasil. Ministério da Saúde (MS). Lei no 10.216, de 6 abril de 2001. Dispõe sobre a proteção e os direitos das pessoas portadoras de transtornos mentais e redireciona o modelo assistencial em saúde mental. Diário Oficial da União 2001; 9 abr.

4. Amarante P. Saúde Mental e atenção psicossocial. Rio de Janeiro: Fiocruz; 2007.

5. Barbato A. Psychosocial rehabilitation and severe mental disorders: a public health approach. World Psychiatry 2006; 5(3):162-163.

6. Brasil. Ministério da Saúde (MS). Secretaria de Atenção à Saúde. Relatório de Gestão 2003-2006: saúde mental no SUS: acesso ao tratamento e mudança do modelo de atenção. Brasília: Ed. Ministério da Saúde; 2007.

7. Habermas J. Teoría de La acción comunicativa. Madrid: Taurus; 1988.

8. Habermas J. Técnica e ciência como ideologia. $70^{\circ}$ Edição. Lisboa; 1987.

9. Campos GWS. Saúde pública e saúde coletiva: campo e núcleo de saberes e práticas. Cien Saude Colet 2000; 5(2):219-230.

10. Hannigan B. Joint working in community mental health: prospects and challenges. Health Soc Care Community 1999; 7(1):25-31.

11. Ayres JRCM. Sujeito, intersubjetividade e práticas de saúde. Cien Saude Colet 2001; 6(1):63-67.

12. Wiggershaus R. A Escola de Frankfurt: história, desenvolvimento teórico, significação pública. Rio de Janeiro: DIFEL; 2006.

13. Merhy EE. Um ensaio sobre o médico e suas valises tecnológicas. Interface (Botucatu) 2000; 4(6):109-116.
14. Barros S, Oliveira MA, Aranha e Silva AL. Innovative practices for health care. Rev Esc Enferm USP 2007; 41(N. Esp.):815-819.

15. Campos GWS. Um método para análise e co-gestão de coletivos, a constituição do sujeito, a produção de valor de uso e a democracia em instituições: o método da roda. São Paulo: Hucitec; 2000.

16. Kirschbaum DI. Nursing agents' perceptions on their work in mental health with psychotic patients in a psychosocial community center. Rev Lat Am Enfermagem 2009; 17(3):368-373.

17. Tanaka OY, Mello C. Avaliação de programas de saúde do adolescente: um modo de fazer. São Paulo: EDUSP; 2004.

18. Almeida PF, Escorel S. Da avaliação em saúde à avaliação em Saúde Mental: gênese, aproximações teóricas e questões atuais. Saúde Debate 2001; 25(58): 35-47.

19. Onocko-Campos R, Furtado JP. Entre a saúde coletiva e a saúde mental: um instrumental tecnológico para avaliação de rede de Centros de Atenção Psicossocial (CAPS) do Sistema Único de Saúde. Cad Saude Publica 2006; 22(5):1053-1062.

Artigo apresentado em 20/04/2012

Aprovado em 27/05/2012

Versão final apresentada em 07/06/2012 